\title{
Kenya's Political Discourse Topics Difference during Presidential Campaigns five Months before 2007 and 2013 Elections.
}

\author{
Francis Kariithi
}

\begin{abstract}
Language has always been used as a political and social weapon in Kenya with politicians embracing varied strategies that are aimed at promoting aparticular interpretation of a social issue. With the constitutional changes that took place in Kenya, it was not clear whether politicians were to be more guarded in their choice of language for fear of being prosecuted for propagating hate speech. In view of the aforementioned, this study set out to undertake a Comparative Political Discourse Analysis by investigating different Discourse Topics five months before 2007 and 2013 elections. The theory that guided the study was Discourse-Historical Approach (DHA). Descriptive method of analysis was employed. Purposeful sampling strategy (Critical case sampling) was used to collect data of politician's reported utterances during the period under study. The main players were; Raila Odinga, Uhuru Kenyatta and William Ruto because during both 2007 and 2013 elections campaign these personalities were among the most pronounced politicians who played pivotal role during presidential campaigns. The data was collected from The Daily Nation and the Standard newspapers. The main Discourse Topics employed by the said politicians formed the basis of the analysis. The study found out that the general choice of discourse topics by politicians is guided by society's most salient historical issues such as the land question and vote rigging. The significance of this undertaking is that; the choice of Discourse Topics during presidential campaigns can be seen as a purveyor of social issues and therefore political situations - and Discourse Topics can also be seen as a driving force directed at changing politics and society.
\end{abstract}

Keyword: Presidential Discourse Topics

\section{INTRODUCTION}

Presidential campaigns in Kenya have always been tailored by politicians to suit well with the prevailing situation at hand. During presidential campaigns Discourse Topics play crucial role in shaping would be campaigns since electorate has always gauged performance of politicians on the most pertinent issues touching on the society. In view of the aforesaid; understanding different political discourse topics in Kenya during presidential campaigns five months before 2007 and 2013 elections is of some importance.

\section{LITERATURE REVIEW}

While quoting Brown and Yule (1983); Crystal and Davy (1969), Habwe (1999:181) observed that the difference between ordinary talk and any other form of discussion is that, ordinary talk has no specific topic that is identified prior to commencement of the talk. He cited that topic assignment is always reached by the participants depending on the rules of engagement. Habwe (1999) went further to say that during political speeches situation is somehow complex since topics are assigned in any basic arrangement before assigning license. In regard to Haugerud and Njogu (1991) observation, Habwe (1999) said that their position was, when any group of politician organizes for a political rally they must moot the nature of discourse topics that are to feature in their speeches though other emerging issues may play out. In his investigation of Swahili political speeches, Habwe (1999:21) was interested in the notion of topic, its management and how it functions as a coherence principle. In accordance to the said scholar observation, topic framework is composed of elements which the speaker and the addressee share and which give the topic of their discussion direction and this may be elements both from physical context such as place, and preceding text of discourse.

Reisigl and Wodak (2001:91) observed that interdiscursivity signifies that discourses are linked to each other in various ways. He retaliated that if one conceives of discourse as primarily topic related, then an individual will observe that, a discourse on climate change frequently refers to topics or subtopics of other discourses, such as finances or health. In conclusion, discourses are open to and often hybrid; new sub-topics can be created at many points. Van Dijk (2001:68), in Wodak and Meyer (2001) advocated that while beginning Critical Analysis one should analyse semantic macrostructures that was, with a study of global meaning, topics or themes. He said that for contextual reason topic should be selected since they are a significant structure to study because they are usually controlled by powerful speakers, because they influence many other structures of a discourse, and because they have the most obvious effects on the recipients and hence on the process of reproduction that underlies social power and dominance. Those were what discourses were about; in that they 
Kenya's Political Discourse Topics Difference during Presidential Campaigns five Months before..

are always intentional and consciously controlled by the speaker since they embody the most important information of a discourse. Reisigl and Wodak (2001:90) in Wodak and Meyer (2001) observed that texts are linked to other texts, both in the past and in the present. In such situations connections are established in different ways; such as explicit reference to a topic or main actor; through references to the same events; by allusions or evocations; by transfer of main arguments from one text to the next, and so on. They continued to cite that the process of transferring given elements to contexts is refered as recontextualization; if an element is taken out of a specific context, they observed it as the process de - contextualization; and if the respective element is finally inserted into a new context the process of recontextualization are realized. According to these scholars in connection to the aforementioned, the element will partly be said to have acquired new meaning, because meanings are formed in used. Their observation was fitting squarely into this study because their observation was tailored into political speech since they alluded that recontextualization could be realized when contrasting a political speech with the selective reporting of the speech in various newspaper.Since this study was targeting specific quotes which could have fitted in the general purpose of the study, it was prudent for the researcher to assign specific quotes to their discourse topics since that was the main reason of the study. The researcher confined himself to the period under study since a number of discourse topics were in line with historical aspects as realized in various quotes of the three politicians.

\section{OBJECTIVE OF THE STUDY}

The objective of the study is to examine differences in political discourse topics five months before 2007 and 2013 presidential campaigns in Kenya?

\section{RESEARCH QUESTION}

Were there differences in political discourse topics five months before 2007 and 2013 presidential campaigns in Kenya?

\section{METHODOLOGY}

This study employed descriptive survey design. Orodho (2003) observed that descriptive data analysis is usually relied on by researchers because it can give researchers time to collect data, to condense data, to interprete and present. Data was purposively sampled; Patton (1990:169) observed that; the logic and power of purposeful sampling lies in selecting information-rich cases for study in depth. According to him, informationrich cases are those from which one can learn a great deal about issues of central importance to the purpose of the research, thus the term purposeful sampling. In connection to purposeful sampling the researcher used critical case sampling. Patton (1990:174) observed that, another strategy for selecting purposeful samples is to look for critical cases. Critical cases are those that can make a point quite dramatically or are, for some reason, particularly important in the scheme of things. Because assisgning of various quotes to discourse topics were to be realized by reading Daily Nation and The Standard newspapers thus enabling variable sampling to be addressed. Politicians who were targeted as the source of ascertaining various discourse topics from their quotes from the said newspaper were Uhuru Kenyatta, William Ruto and Raila Odinga. Approximately 208 quotes from the three politicians were sampled and subsequently aligned with individual discourse topics. The researcher relied on graphs as means to comparing 2007 and 2013 discourse topics. According to Kastellec and Leoni (2007), they observed that, graphs are superior at displaying confidence intervals for parameter estimates (and thus their uncertainty) and for making comparisons across models. They believed that scholars who follow their advice were likely, both understand their data better and present their empirical results more clearly to their audience, thereby increasing the value and impact of their research. Since the researcher intended have his findings to impact positively on his audience he used graphs for each discourse topic alongside the said politicians. These graphs were such as:

Graph 1.5 Discourse Topics on Rigging in 2007 and 2013

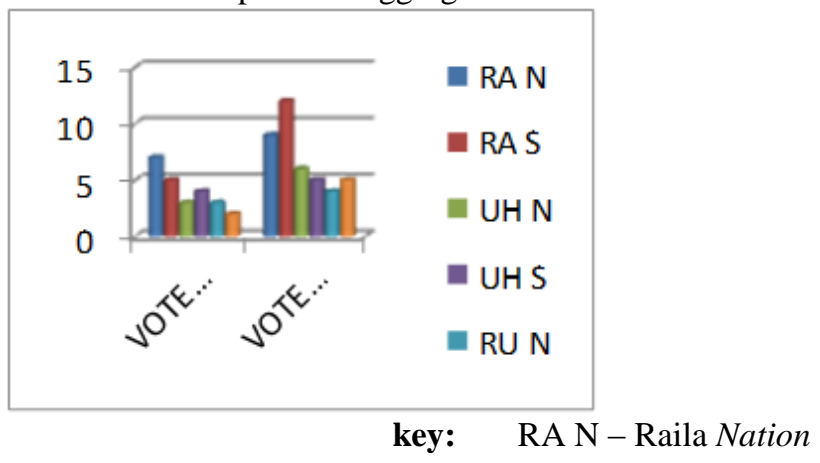




\author{
RA S - Raila Standard \\ UH N - Uhuru Nation \\ UH S - Uhuru Standard \\ RU N - Ruto Nation \\ RU S - Ruto Standard
}

\title{
VI. FINDINGS AND DISCUSSION
}

It is worth to note that this study's intention was to investigate political discourse topics in Kenya during presidential campaigns five months before 2007 and 2013 elections. In view of the above this study confined itself to the discourse topics that played out within the period under study. The choice of various political discourse topics by the said politicians largely depended on the community's most salient issues and on the manner it may have impacted on the community. In essence historical question was vital into driving the direction one given topic was headed. The most salient political discourse topics were vital ingredients used by the politicians to spice up their campaigns. Discourse topics that played out during the period under study fitted well in the politician's ideological frames as indicated:

1. Stressing our good ideals

2. Stressing their bad ideals

3. Not stressing our bad ideals

4. Not stressing their good ideal

Van Dijk (2006) observed that the aforementioned ideological frames can be employed in all levels of speech acts, meaning and in any kind of text and discourse. Therefore, political speeches, debates, plans and propaganda in essence aims at associating ones group with pleasants things or events that they may have exhibited or that they may be yearning to undertaking. On the other hand members of opposition from the other group are usually associated with ugly occurrences such as land clashes, drug abuse, and suffocation of freedom and many other myriads practices. According to van Dijk (2006), topics and meanings comprise chapters and structures; meaning may be stressed or upgraded in various forms, such as, intonation, observing, word arrangement, by assigning titles, repetition and so on. In the contrary the worst will always happen when the bad things are being done. Issues that are unpalatable in connection with their political foes - such as insecurity of their country, will always appear in the headline with derogatory and broad writing.

Whilst analysing data it was established that these politicians addressed on the most salient historical issues that could easily persuade the electorate, since it is worth of note that politicians are to embrace discourse topics that can easily deliver the intended vote. In order for the envisaged intention to be achieved; these politicians tailor their speeches with and aim to disparaging others and on the other hand promoting their own chances of attracting voters. Going by the evidence adduced by this study it is clear those political discourse topics that could easily be seen to soil one group chances of attracting support was meticulously engaged by 'us' against 'them'. The idea was aimed at strictly employing van Dijk (2006) discourse ideological frames.

Five months before 2007 elections, presidential campaign attracted discourse topics such as tribalism, vote rigging, integrity, political parties and coalitions, regionalism and constutionalism, factors of former presidents among other crucial issues. In essence, discourse topics selection was instigated by politician's competition mood since one discourse topic targeted the other's foe in line with where the said campaigns were being held. During 2007 presidential campaigns retired president Kibaki and Raila were aspiring to capture presidency seat and therefore discourse topics that featured prominently had one agenda; to disparage the other. Raila mainly targeted Kibaki's weakness against his articulate strength if only Kenyans were to accord him that prestigious chance.

William Ruto who was Raila's compatriot during 2007 presidential election confined himself prominently on the very discourse topics since they were operating as a unit. Their speeches had one crucial agenda; that of disparaging PNU and her proponents under the leadership of Mwai Kibaki who wanted to make a come back.

During 2007 presidential campaigns, Uhuru Kenyatta opted to support the incumbent with an aim to enhance Kibaki's chance of recapturing that coveted seat. His decision to supporting Kibaki was castigated by Raila and his die hards. Uhuru was viewed as tribal chauvinist because it was associated with the 'old' from Mount Kenya region. Because of the scathing attack directed on him, Uhuru Kenyatta did not come out strongly during 2007 campaigns if this study's data is anything to go by. Uhuru in his campaigns talked on matters touching on KANU, retired president Moi, reasons why he supported Kibaki, the importance of Mount Kenya region to support Kibaki among other issues.

According to the 2012-2013 analysed campaign data before 2013 election, it is clear that there were some significant differences since party coalitions were different from that of 2007. Coalitions that were there were CORD, Jubilee, Amani so were political parties whose aim was to capture that presidential seat if voting could have favoured them. Following that pronounced change, political discourse topics were different in terms 
Kenya's Political Discourse Topics Difference during Presidential Campaigns five Months before..

of frequency and nature from those of 2007. The change that was being experienced can be pegged to emerging of difference occurrences after 2007 elections. Political discourse topics that found their way in Kenya's presidential campaigns in 2013 elections were tribalism, land question, integrity, The Hague factor, constitution, age factor, vote rigging among other issues.

The change on appreciation or depreciation concerning the frequency on how one issue attracted more attention than the other during presidential campagns was instigated by the fact that presidential aspirants had changed, so were political party's coalitions. Factors that raised the tempo on political heat in campaigns trails were tribalism, land and The Hague factor. The manner, in which land factor featured in 2007 presidential election campaigns, resonated in an appreciated frequency during 2013 presidential campaigns. This study established that the probable reason on that occurrence may have emanated from one thing - Raila dreaded a situation where by he could have disparaged himself with Ruto in the fold. In any case, Ruto had also been quoted to having castigated Ndungu Land Commission over its manner of handling casually that historical issue.

In view of the issue touched above, the study established that Raila steered away from the land question in 2007 in comparison to 2013 election campaigns where he was being quoted every other time talking about land - this was a historical diatribe against Uhuru and Ruto. Another political discourse topic that raised political heat was International Criminal Court cases against the duo (Uhuru and Ruto) in The Hague. In a nut shell, issues that found their way in 2013 presidential elections campaigns were critical to Jubilee fold since they were both historical and contemporary alike. While addressing parsuation factor Reisigl and Wodak (2001) observed that to be an intentional undertaking whose aim should be to affect people and pave way for change on his personal stand, attitude and conviction so that he can work from both ends. In conclusion, Reisigl and Wodak (2001) two edges were, 'to exalt ones group' and 'to demean the other group'.

\section{CONCLUSION}

In reference to the research question; this study established that selection of political discourse topics in Kenya are tailored to fit perfectly on the society's most salient issues. In essence, the established fact is that, political discourse topics are essential since they are indicators of issues that affect the community at that pointing time, whether they are historical or they may have emerged during campaigns. If an individual or an earlier government may have exhibited lacrustre performance in her governance; preceding presidential campaigns in other subsequent years may borrow a lot from her yester years' undertaking. The study found out that political discourse topics may end up changing; a change that may be precipitated by different aspirants aspiring for the said seat, historical issues touching on the aspirants and other emerging issues. In conclusion and in connection to 2007 and 2012 - 2013 political discourse topics, it was established that issues touching on presidential elections are not static since they may change depending on aspirants, historical occurrences and any other issue that may end up being an apt ingredient in attracting and persuading electorate on one hand and on the other hand disparaging ones' opponents.

\section{REFERENCES}

[1]. Chilton, P. (2004) Analysing Political Discourse: Theory and Practice. London: Routledge.

[2]. Habwe, J. (1999). Political Rally Speeches in Kenya. Nairobi: University of Nairobi.

[3]. Haugerud, A and Njogu, S.K (1991) State Voices in the Country Side: Politics and the Kenyan Baraza. African Studies Center, Boston University.

[4]. Kastellec, J., and Leoni, E. (2007). Using graphs instead of tables in political science. Perspectives on Politics 5, 755771.

[5]. https://www.google.com/?gws_rd=ssl\#q=using+graphs+instead+of+tables+in+political+science. 27/10/2015. 9.58 $\mathrm{pm}$

[6]. Kenya National Commission on Human Rights. On the Brink of the Precipice: A Human Rights Account of Kenya's Post-Election Violence. $15^{\text {th }}$ August 2008. Nairobi: 2007.23-129

[7]. KNCHR, Kenya National Commission on Human Rights (2008). On the Brink of the Precipice: A Human Rights Account of Kenya's Post-Election Violence. Nairobi: KNCHR. Kriegler Report (2008).

[8]. The Independent Review Commission on the General Elections: Nairobi.

[9]. https:// rescuekenya. wordpress. com/ 2008/... /kreigler-report-report-of-the-...Report of the Independent Review Commissio on the General Elections held in Kenya on 27 December 2007

[10]. Lyenger. S \& Mcgrady. J. (2007) Media Politics: A Citizen Guide. WW Norton \& Company: London.

[11]. Oduori, R. (2009). "Lugha na Siasa Nchini Kenya: 2005." Tasnifu ya Uzamifu ambayo Haijachapishwa. Eldoret: Chuo Kikuu Moi.

[12]. Onyango, J.O. (2008). Ethnic Discourse on Contentious Issues in the Kenyan Press after the 2007 General Elections. Presented at $12^{\text {th }}$ General Assembly,CODESRIA.

[13]. Orodho, A. J (2003) Essentials of Education and Social Science Research Methods.Nairobi: Masola Publishers.

[14]. Patton, M. (1990) Qualitative evaluation and research methods (pp. 169-186). BeverlyHills, CA: Sage.

[15]. http://legacy.oise.utoronto.ca/research/field-centres/ross/ctl1014/Patton1990.pdf29/10/2015

[16]. Reisigl, M. na Wodak, R. (2001) The discourse- historical approach (DHA): history, agenda theory and methodology. In R. Wodak na M, Meyer (Eds). Methods of Critical Discourse Analysis (2ed). London: SAGE. 
Kenya's Political Discourse Topics Difference during Presidential Campaigns five Months before..

[17]. Reisigl, M. and Wodak, R. (2001) Discourse and Discrimination; Rhetorics of racism and anti-Semitism: Routledge. London.

[18]. Van Dijk, T. A. (2006). Politics, Ideology, and Discourse: Barcelona. Elsevier Ltd.

[19]. Waki Report (2007/2008). Commission of Inquiry into Post-Election Violence (CIPEV): Nairobi.

[20]. Wodak, R. na Meyer, M. (2001) Critical Discourse Analysis: History, Agenda, Theory and Methodology. In R. Wodak and M, Meyer (Eds). Methods of Critical Discourse Analysis 2ed. London: SAGE. 